\title{
POLISH PRESIDENTIAL ELECTION OF 2010: A STUDY OF THE POWER OF VOTERS IN BIG AND MEDIUM-SIZED TOWNS
}

\author{
*ROMAN MATYKOWSKI and **KATARZYNA KULCZYŃSKA \\ ${ }^{*}$ Institute of Socio-Economic Geography and Spatial Management, \\ Adam Mickiewicz University, \\ Dzięgielowa 27, 61-680 Poznań, Poland \\ E-mails: *mat@amu.edu.pl, **katakul@amu.edu.pl
}

\begin{abstract}
In the literature on the subject, urbanisation is regarded as one of the most important factors shaping electoral behaviour. The effect of this factor has also been corroborated by studies in Poland, where one can speak of urban- and rural-oriented parties. To determine the significance of the urban electorate in Poland, use was made of the procedure of backward elimination of voters in the successive biggest towns. The next step involved identifying the structure of support for the leading presidential contenders in the 2010 election at each stage of the rank elimination of the towns. It was already in the parliamentary elections at the start of the 21st century that big cities and the larger of medium-sized towns turned out to be their "engines": with their highest voter turnouts, they crucially affected the results at the national scale. That is why an analysis was made of voter alignment in towns of this size category over the years 2001-2007, and on this basis various electoral types of towns were distinguished.
\end{abstract}

Key words: big and medium-sized towns, electoral types of towns, Poland

\section{INTRODUCTION}

It is a shared aim of many geographical studies of the spatial variability of a phenomenon to seek and identify factors responsible for this heterogeneity. That is why their routine procedure is to establish and list fáctorors (vâriables) affecting the spatial structure of the phenomena under analysis. A less popular approach is to dwell on the definition of a factor and its categorisation, although in this case use is often made (e.g. Rogacki 1988) of the definition formulated by Chojnicki and Czyż (1978) for the purposes of factor analysis employed in spatial studies. In their approach, a factor distinguished is a quantity "significantly affecting other quantities, whether it is a classificatory or an ordering one" (Chojnicki and Czyż 1978, p. 11). Sometimes a separate category-that of determinants (conditions) - is distinguished from the generál category of fáctorss. Factors are assigned properties that are active and readily controllable, while conditions are seen as rather passive and hard to control (cf. Chojnicki 1998).

In electoral studies-depending on a socio-political or a spatial context-representátives of various disciplines often accuse their opponents of ignoring those dimensions, so there have appeared proposals to solve the 
dispute by differentiating between spatial and structural factors (cf. Zarycki 1997). As Zarycki (1997, p. 49) observes, "one of the ways to differentiate spatial factors from structural ones is using the theoretical schema adopted by Rokkan and Lipset"; still, when discussing studies of conflicts carried out in accordance with this schema, he had to admit that the effect of a structural factor can "turn into a spatial factor connected with the specificity of a place" (p. 51).

That is why in geography attempts have been made to approach factors in two ways. First, a factor is treated as a pre-theoretical kind of notion and as such is ascribed some impact, e.g. factors in migration models, factors of location of an economic activity, or factors of urban growth (not always connected with concrete theoretical models or theories). Secondly, unlike representatives of other disciplines dealing with elections, geographers rely on a chorological approach and often seek to establish the force of impact of various factors - e.g. on the level of electoral support - on the basis of the cooccurrence of variables studied in territorial terms. To assess the strength of co-dependence of the variables, they usually employ correlation analysis, although the measure they also sometimes use is that of geographical distribution (a modification of Florence's index). What raise doubts, in turn, are attempts at interpreting the co-occurrence of electoral variables and socio-economic variables in terms of a cause-and-effect relationship.

It should be noted that in geography the notion of factors often serves to build theory or pre-theories that also deal with spatial differences in the electoral behaviour pattern. From á mácróanalytic perspective on territorial systems ranging from the subregional to the macro-regional level, three groups of conceptions of the impact of factors and determinants can be distinguished: (1) those of historical-cultural conditions; (2) modernisation conceptions, or those of the effect of some socio-economic factors; and (3) those connected with rivalry and conflicts within a country's political system. As early as 1989, a well-known article by Florczyk et a1. published in the Tygodnik Solidarnośc announced a "return of history" and macro-regional divisions, also those still running along the former partition boundaries. There were further elaborations of this approach to macro-regional heterogeneity, e.g. conceptions of a historical background (cf. Bartkowski 2003), civilisation-determined macro-regions and civilisation-determined split of the country, or electoral "geology" (Kowalski 2003). A more comprehensive model of the effect of historical determinants (events in earlier ages treated as analogous to sedimentation layers) on modern political culture in Poland was presented by Zarycki (2001). He claims that what inspired him to seek this type of explanation of political behaviour patterns was Dogan's (1967) study of electoral behaviour in France and Italy.

In the conceptions of society modernisation, the most important category of factors-from a micro-analytic perspectiveincludes those describing the processes of both urbanisation and industrialisation (cf. Anduiza-Perea 1999, Cześnik 2007). In the conditions of Central and East European states, this category of factors includes parameters describing their socio-political and economic transformation (e.g. the unemployment rate). Also in Poland, from the very first free, democratic Sejm (parliamentary) elections of 1991, a factor controlling the variability of regional support for individual parties has been the urbanisation level (cf. Matykowski et al. 1995).

As Parysek et al. (1991) found on the basis of multivariate regression analysis, the pattern of differences in regional support for Tadeusz Mazowiecki in the 1990 presidential election depended in a significant and direct proportion on such social factors as: the share of females, people of the working age, people from regions with a high proportion of non-private land, persons with secondary and higher education, and persons with lower-secondary vocational education. In turn, using the principal components method to characterise the presidential elections of 1990 and 1995 as well as the parlia- 
mentary elections of 1991 and 1993, Zarycki (1997) distinguished two cleavages for all those variables, consistently interpreted as factors contrasting the electoral system: 'town-countryside' and 'the right-the left'. Next he employed this method to characterise the regional socio-economic system, and distinguished two factors that contrasted it: 'town-countryside' and 'old regions-new regions'. In this way Zarycki sought to match endogenous factors with exogenous ones making use of Lipset-Rokkan's approach.

Thus, the factor shaping the alignment of voters in Poland at various territorial levels is competition along the axes of 'right/ left-oriented parties' and 'urban/rural-oriented parties' (cf. Zarycki 1997, Matykowski 2007). Despite the radical changes in the Polish political area at the start of the 21 st century, some political parties-both new and old-have still preserved, or assumed, the features of urban or rural groupings.

\section{RESEARCH AIM AND ASSUMPTIONS}

The aim of this paper is to analyse the effect of the electorate of big and medium-sized Polish towns on the results of the presidential election of 2010, and to characterise voter alignments in towns of this size category. The analysis will cover the following detailed issues:

(1) the effect of the hundred biggest towns on the national results of the election;

(2) determination of the types of towns (from the subset of big and the larger of medium-sized ones) on the basis of indices of electoral support;

(3) determination of the anticipated level of support in the 2 nd round of voting in the presidential election in the subset of towns under analysis; and

(4) an assessment of the effect of the electorate of big and medium-sized towns on the regional election results.

In the analysis use was made of the presidential election returns published by the State Election Commission. For most of the analysed towns, those were data con- cerning units with a status of independent communes, but in a few cases (e.g. Nysa, Chrzanów, Wolomin) where a town formed an urban-rural commune together with the surrounding area, additional calculations had to be made relying on data from constituencies.

It is usually assumed that a population of 20,000 provides the statistical threshold separating small and medium-sized towns (cf. Zuzańska-Żyśko 2006). However, Heffner (2008) argues that most settlement units of up to 25,000 population can be characterised by the same variables as the group of small towns. Hence in the present research the lower population limit for a medium-sized town was set arbitrarily at 35,000. This step was prompted by the desire to select the larger of the medium-sized towns while excluding those with fluid properties characterising, in Heffner's opinion, both small and medium-sized towns.

In December 2009, Poland's 897 towns accounted for $61.0 \%$ of the country's total population (after the GUS Regional Research Statistics), with $28.7 \%$ of the total population living in big towns and $13.3 \%$ in medium-sized ones (the two groups together accounting for $42.0 \%$ of the total population). However, in the parliamentary elections of 2007 the residents of those towns made up as much as $48.7 \%$ of all voters in the country, and in the 2010 presidential election, $45.9 \%$ of voters in the 1 st round and $44.3 \%$ in the 2 nd round. The drop in the proportion of voters from big and medium-sized towns was largely a result of the start of the holiday season and tourists from big cities casting their votes not in their places of residence, but in their holiday destinations.

\section{IMPACT OF THE ELECTORATE OF THE HUNDRED BIGGEST TOWNS ON THE RESULTS OF THE 2007 SEJM ELECTIONS AND THE 2010 PRESIDENTIAL ELECTION: THE 'SCISSORS' EFFECT}

In analysing the effect of the electorate of the biggest towns in Poland on the election 
results, returns from abroad were ignored, as in Śleszyński (2007a) and Matykowski (2010). The procedure employed was that used in Matykowski (2010), involving the ordering of the 100 biggest towns by size in the 2010 presidential election and the preceding 2007 Sejm elections, the criterion being the number of eligible voters in the given town rather than its population. It should be noted that the 2010 presidential election was an early one (owing to the tragic death of the previous President) and was held at the beginning of the summer holiday season. That is why differences in the number of eligible voters in some medium-sized towns between the 1 st and the 2 nd round could be significant. For example, in the 2007 parliamentary elections Kolobrzeg occupied 97th position in size ranking, while in the 2010 ballot it moved up to 87 th position in the 1 st round of voting and as high as 81 st in the 2 nd round owing to the inflow of tourists. The next procedure employed was that of backward elimination of successive big towns; established at each stage of their elimination was the structure of support for the two leading presidential candidates in the 1st and 2 nd rounds of voting and for the two major parties in the 2007 Sejm elections (from which the two contenders derived). The elimination procedure and the analysis of the support structure were carried out along the following lines:

(1) the election returns of successive biggest towns were eliminated and their level of support for each party or candidate determined at each stage of elimination, with the support expressed in terms of the proportion of valid votes;

(2) the results of the successive biggest towns were eliminated again, but this time the support index was defined in terms of the number of eligible voters (thus reducing the effect of voter turnout on the structure of support and allowing a comparison of the results of various elections, often differing in the activity of the electorate); and

(3) only those big cities were eliminated in which the advantage of the leading can- didate or party over its competitor was greater than the national average.

As has been established by Matykowski (2010), in the 2007 Sejm elections it was only after the elimination of $93 \mathrm{big}$ and mediumsized towns (the last one excluded was Nysa) that the party Law and Justice (PiS) would have scored a success in the rest of Poland $(34.9 \%)$, while at the scale of the country the victorious party was the Civic Platform (PO) with $41.4 \%$ of valid votes (in the towns eliminated from the settlement sub-system this party captured a much higher proportion of the vote, at $49.38 \%$; cf. Table 1). Those 93 eliminated towns were inhabited by $38.6 \%$ of eligible voters, or $38.3 \%$ of the total population, and they covered $2.7 \%$ of Poland's area. On analysing the presidential election, one could find that the impact of the biggest towns was even more obvious. In the 1st round of voting Bronisław Komorowski won $41.5 \%$ of valid votes in the country and Jarosław Kaczyński-36.5\%. However, on the backward elimination of 18 big towns (the 18th being Gliwice), the winner in the rest of the country would have been the latter (38.6\% of the vote). In the 18 eliminated towns Komorowski collected $50.4 \%$ of valid votes (Table 2 ). Those towns covered $1.2 \%$ of Poland's territory and accounted for $21.2 \%$ of its population. Thus, Komorowski owes his success in principle to the electorate of the 18 biggest cities. Naturally, here too the generalisation is not quite correct, because there were also towns among them that gave Kaczyński above-average support (Lublin, Radom). Those tendencies of change in voter alignment with the elimination of the successive biggest towns are presented in Fig. 1 and Table 2.

The crisscrossing lines of support for the two leading parties in the 2007 elections and the two leading candidates running for president in the 2010 ballot resemble the blades of a pair of scissors. The 'electoral scissors' effect only occurs in the specific conditions of competition between two parties splitting the vote rather evenly and a strong influence of the electorate of big and medium-sized 
Table 1. Electoral features in the biggest-cities versus rest-of-country division in the Sejm election of 2007

\begin{tabular}{|c|c|c|c|c|c|c|c|c|c|}
\hline \multirow[b]{3}{*}{ Range characteristics } & \multirow[b]{3}{*}{$\begin{array}{l}\text { voter } \\
\text { turnout } \\
(\%)\end{array}$} & \multicolumn{8}{|c|}{ Towns by size (number of eligible voters) } \\
\hline & & \multicolumn{2}{|c|}{$\begin{array}{l}\text { level of support } \\
\text { (\% of valid } \\
\text { votes) }\end{array}$} & \multirow[b]{2}{*}{$\begin{array}{l}\text { voter } \\
\text { turnout } \\
(\%)\end{array}$} & \multicolumn{2}{|c|}{$\begin{array}{l}\text { level of support } \\
\text { (\% of valid } \\
\text { votes) }\end{array}$} & \multirow[b]{2}{*}{$\begin{array}{l}\text { last town } \\
\text { eliminated } \\
\text { from subset }\end{array}$} & \multicolumn{2}{|c|}{$\begin{array}{l}\text { size } \\
\text { characteristics } \\
\text { of eliminated } \\
\text { urban area }\end{array}$} \\
\hline & & $\begin{array}{l}\text { for } \\
\text { PiS }\end{array}$ & $\begin{array}{l}\text { for } \\
\mathrm{PO}\end{array}$ & & $\begin{array}{l}\text { for } \\
\text { PiS }\end{array}$ & $\begin{array}{l}\text { for } \\
\text { PO }\end{array}$ & & $\begin{array}{l}\% \\
\text { of area }\end{array}$ & $\begin{array}{l}\% \text { of } \\
\text { popu- } \\
\text { lation }\end{array}$ \\
\hline Poland (without Poles abroad) & 53.72 & 32.13 & 41.36 & $\mathrm{x}$ & $\mathrm{x}$ & $\mathrm{x}$ & $\mathrm{x}$ & 0.00 & 0.00 \\
\hline Without 25 biggest cities & 50.16 & 33.81 & 37.08 & 64.65 & 28.19 & 51.42 & Rybnik & 1.40 & 24.53 \\
\hline Without 50 biggest cities & 49.43 & 34.59 & 35.94 & 63.03 & 28.01 & 50.49 & $\begin{array}{l}\text { Ostrowiec } \\
\text { Swiętokrzyski }\end{array}$ & 2.02 & 31.42 \\
\hline Without 93 biggest cities & 48.72 & 34.93 & 34.92 & 61.70 & 28.66 & 49.38 & Nysa & 2.66 & 38.30 \\
\hline Without 100 biggest cities & 48.61 & 34.96 & 34.80 & 61.59 & 28.75 & 49.23 & Sieradz & 2.73 & 39.15 \\
\hline
\end{tabular}

Source: own calculations on the basis of the State Electoral Committee and Central Statistical Office data.

Table 2. Electoral features in the biggest-cities versus rest-of-country division in the presidential election of 2010

\begin{tabular}{|c|c|c|c|c|c|c|c|c|c|}
\hline \multirow[b]{3}{*}{ Range characteristics } & \multirow[b]{3}{*}{$\begin{array}{l}\text { voter } \\
\text { turnout } \\
(\%)\end{array}$} & \multicolumn{8}{|c|}{ Towns by size (number of eligible voters) } \\
\hline & & \multicolumn{2}{|c|}{$\begin{array}{l}\text { level of support } \\
\text { (\% of valid } \\
\text { votes) }\end{array}$} & \multirow[b]{2}{*}{$\begin{array}{l}\text { voter } \\
\text { turnout } \\
(\%)\end{array}$} & \multicolumn{2}{|c|}{$\begin{array}{l}\text { level of support } \\
\text { (\% of valid } \\
\text { votes) }\end{array}$} & \multirow[b]{2}{*}{$\begin{array}{l}\text { last town } \\
\text { eliminated } \\
\text { from subset }\end{array}$} & \multicolumn{2}{|c|}{$\begin{array}{l}\text { size } \\
\text { characteristics } \\
\text { of eliminated } \\
\text { urban area }\end{array}$} \\
\hline & & $\begin{array}{l}\text { for } \\
\text { J. Ka- } \\
\text { czyński }\end{array}$ & $\begin{array}{l}\text { for } \\
\text { B. Ko- } \\
\text { moro- } \\
\text { wski }\end{array}$ & & $\begin{array}{l}\text { for } \\
\text { J. Ka- } \\
\text { czyński }\end{array}$ & $\begin{array}{l}\text { for } \\
\text { B. Ko } \\
\text { moro- } \\
\text { wski }\end{array}$ & & $\begin{array}{l}\% \\
\text { of area }\end{array}$ & $\begin{array}{l}\% \text { of } \\
\text { popu- } \\
\text { lation }\end{array}$ \\
\hline \multicolumn{10}{|l|}{ 1st round } \\
\hline Poland (without Poles abroad) & 54.74 & 36.46 & 41.47 & $\mathrm{x}$ & $\mathrm{x}$ & $\mathrm{x}$ & $\mathrm{x}$ & 0.00 & 0.00 \\
\hline Without 18 biggest cities & 52.50 & 38.62 & 38.60 & 63.13 & 29.71 & 50.41 & Gliwice & 1.18 & 21.24 \\
\hline Without 25 biggest cities & 52.37 & 38.88 & 38.26 & 62.22 & 30.03 & 49.98 & Rybnik & 1.40 & 24.33 \\
\hline Without 50 biggest cities & 51.97 & 39.85 & 37.30 & 60.93 & 29.99 & 49.42 & $\begin{array}{l}\text { Ostrowiec } \\
\text { Świętokrzyski }\end{array}$ & 2.02 & 31.14 \\
\hline Without 100 biggest cities & 51.42 & 40.58 & 36.52 & 59.98 & 30.89 & 48.15 & Sieradz & 2.74 & 38.95 \\
\hline \multicolumn{10}{|l|}{2 nd round } \\
\hline Poland (without Poles abroad) & 55.15 & 47.08 & 52.92 & $\mathrm{x}$ & $\mathrm{x}$ & $\mathrm{x}$ & $\mathrm{x}$ & 0.00 & 0.00 \\
\hline Without 17 biggest cities & 53.43 & 50.02 & 49.98 & 61.88 & 37.07 & 62.93 & Toruń & 1.14 & 20.73 \\
\hline Without 25 biggest cities & 53.35 & 50.49 & 49.51 & 60.92 & 37.48 & 62.52 & Rybnik & 1.40 & 24.33 \\
\hline Without 50 biggest cities & 53.13 & 51.69 & 48.31 & 59.73 & 37.72 & 62.28 & $\begin{array}{l}\text { Ostrowiec } \\
\text { Świętokrzyski }\end{array}$ & 2.02 & 31.14 \\
\hline Without 100 biggest cities & 52.72 & 52.78 & 47.22 & 59.04 & 38.90 & 61.10 & Świnoujście & 2.78 & 38.92 \\
\hline
\end{tabular}

Source: own calculations on the basis of the State Electoral Committee and Central Statistical Office data. 


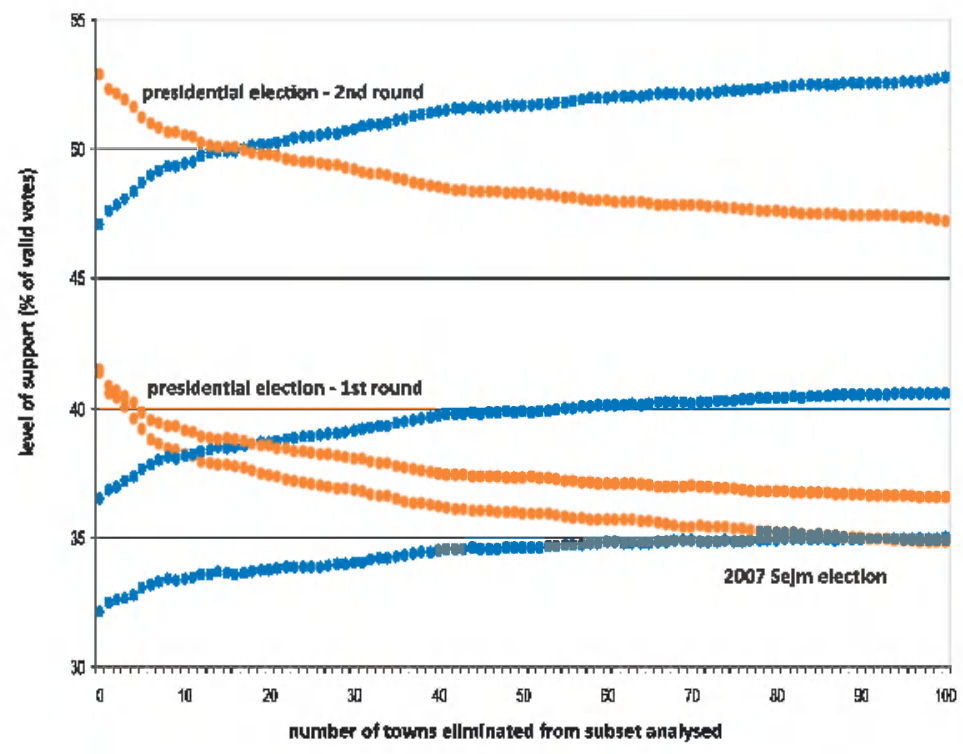

support for PiS in 2007 Sejm election
and for J. Kacyriski in 2010 presidential electian

support for PO in 2007 Sejm election and far J. Kacryóski in 2010 prasidantíal alection

Figure 1. Electoral scissors on elimination of successive towns (down to ranking position 100) in the 2007 Sejm election and the 2010 presidential election

(support calculated as a proportion of valid votes)

towns on the level of voter support for them (or of differences in the level of support for them between urban areas versus rural areas and small towns). The party or presidential contender winning higher support in big and medium-sized towns collects an ever smaller share of valid votes with a successive elimination of those towns from the territorial system analysed, while the support for the party or candidate among the remaining electorate (from the countryside and small towns) rises markedly.

Worth noting are the very significant differences in the voter alignments of the residents of Poland's 18 biggest cities (by the number of eligible voters) and the rest-ofcountry population in the 1 st round of the 2010 presidential election (Table 2). The voter turnout in those towns was $63.1 \%$, as against $52.5 \%$ in the rest of the country. Also the support for Komorowski in this group of towns was very high, more than a half of valid votes $(50.4 \%)$, while in the rest of the country he won less than two-fifth $(38.6 \%)$. To eliminate differences in electoral behaviour resulting from differences in voting activity, an analysis was made of the 'electoral scissors' using a support index defined in terms of the number of eligible voters. The drop in support for Komorowski in 2010 and the Civic Platform in 2007-on the successive elimination of big towns-is much steeper than the rise in support for his rival, Kaczyński (cf. Fig. 2). Also calculated were indices of change (increase or decrease)-analogous to simple coefficients of dynamics-between the level of support for the two leading presidential contenders in the entire country (without returns from abroad) and in the remaining part of Poland left on elimination of the results from the 25 biggest towns (Table 3 ). What corroborates those links between voter turnout and level of support for the two principal candidates calculated for a total of 101 series (starting with the entire national system and 


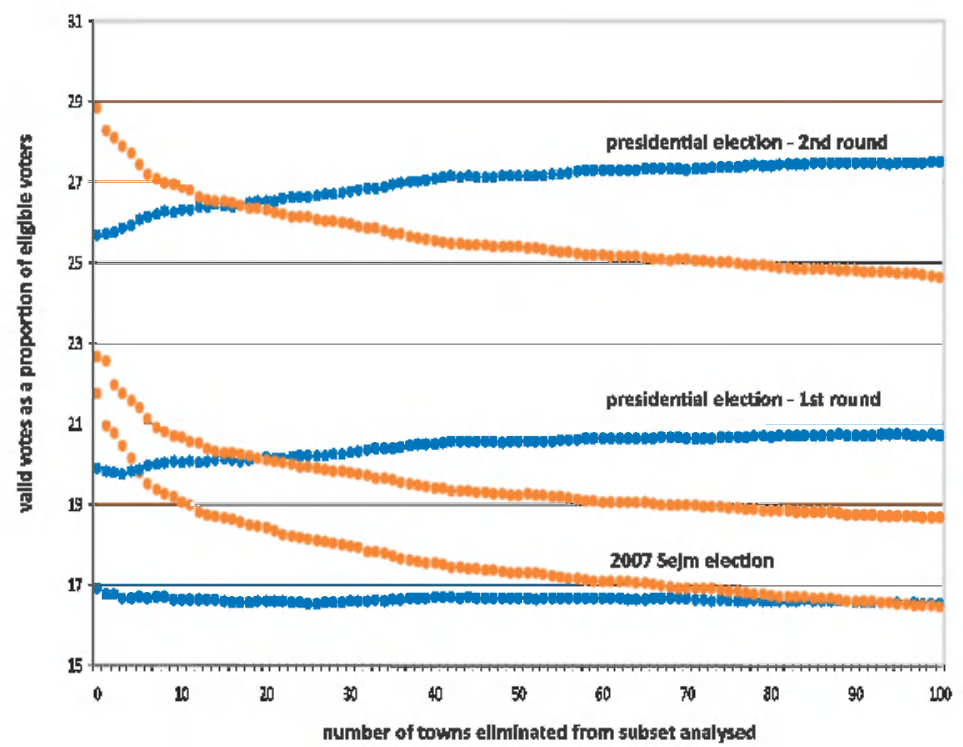

support for PIS in 2007 5ejim election

support far po in 20075 sẹjm election and for J. Kaczyiskl In 2010 preskientlal election

Figure 2. Electoral scissors on elimination of successive towns (down to ranking position 100) in the 2007 Sejm election and the 2010 presidential election (support calculated as a proportion of eligible voters)

then eliminating from it the successive biggest towns, down to a town of rank 100) is the value of the correlation coefficient. In the 1 st round of voting this coefficient of a relationship between the turnout and support was $r=-0.951$ for Kaczyński and $r=+0.996$ for Komorowski. Thus, the higher the voter turnout in the set of towns under analysis, the higher the support for Komorowski and the lower for Kaczyński.

Another important issue visible in the parliamentary elections of 2005 and 2007 and the presidential elections of 2005 and 2010 is competition between the two chief parties of this period and the presidential contenders put up by them. A measure of this competition can be the proportion $\left(w p_{k}\right)$ of the average level of support for Law and Justice in the 2007 elections (and for Kaczyński in 2010) to the average level of support for the Civic Platform (and Komorowski). At the scale of the country, this index looked as follows:
- the 2007 Sejm elections

$$
w p_{\mathrm{k}}=0.7769
$$

- the 2010 presidential election (1st round) $\quad w p_{\mathrm{k}}=0.8791$

- the 2010 presidential election (2nd round) $\quad w p_{\mathrm{k}}=0.8896$.

Since the value of the index was closer to 1 with each successive ballot, it can be stated that in the years 2007-2010 the disproportions in the support for the two main political rivals at the scale of the country kept decreasing, although they were substantial in the particular towns under study. To make analysis easier, a relative proportion index ( $w w p$ ) was calculated by dividing the original indices for individual towns by the average disproportion indices for the country $\left(w p_{k}\right)$. When the $w w p$ index exceeded 1, it meant above-average support for PiS (or Kaczyński), although this need not always be a support prevailing in terms of absolute numbers. In the 2nd round of voting, the highest proportion of the Kaczyński / 
Table 3. Indicators of change in the electoral properties of selected territorial systems in the presidential election of 2010

\begin{tabular}{lllc}
\hline & \multicolumn{2}{c}{ Indicators of change in subsets analysed (\%) } \\
\cline { 3 - 4 } System analysed & $\begin{array}{l}\text { Poland_Poland (after elimination } \\
\text { of 25 biggest cities) }\end{array}$ & $\begin{array}{l}\text { Poland (after elimination } \\
\text { of 25 biggest cities) - Poland (after } \\
\text { elimination of 50 biggest cities) }\end{array}$ \\
\hline 1st round & Voter turnout & -2.57 & -0.76 \\
& $\begin{array}{l}\text { support for J. Kaczyński } \\
\text { (as proportion of eligible voters) }\end{array}$ & +1.61 & +1.72 \\
& $\begin{array}{l}\text { support for B. Komorowski } \\
\text { (as proportion of eligible voters) }\end{array}$ & -13.80 & -3.47 \\
& $\begin{array}{l}\text { Voter turnout } \\
\text { 2nd round }\end{array}$ & -1.80 & -0.40 \\
& $\begin{array}{l}\text { support for J. Kaczyński } \\
\text { (as proportion of eligible voters) }\end{array}$ & +3.78 & +1.98 \\
& $\begin{array}{l}\text { support for B. Komorowski } \\
\text { (as proportion of eligible voters) }\end{array}$ & -10.46 & -2.90 \\
\hline
\end{tabular}

Source: own calculations.

Komorowski support was recorded in the towns of Belchatów (2.15), Jarosław (1.47) and Jasto (1.46); it was slightly above 1 also in Rzeszów (wwp $=1.08$, where Kaczyński captured $48.9 \%$ of the vote) and Tarnów $(w w p=1.02$, with support for this candidate at $47.5 \%$ ). In turn, the lowest values of the proportion index $w w p$ were obtained for Opole (0.40), Poznań (0.43), Sopot (0.43), Zielona Góra (0.45), and Gdynia (0.45). Therefore yet another version of the analysis was designed in which only those big and medium-sized towns were eliminated in which the leading candidate or party gained a greater advantage over their rival than was the national average (i.e. where wwp > 1). To obtain a sub-system eliminating a 100 successive towns (but only those in favour of the Civic Platform, i.e. where $w w p<1$ ), the town that had to be eliminated in the 2007 Sejm elections was one located in the 149th position in the size ranking; in the 1st round of the 2010 presidential election, the 144th town; and in the 2 nd round, the 147th town. In this approach, the 'rest-of-towns' group included all the PiS-oriented towns (or those showing above-average support for Kaczyński). This means that after eliminating 67 successive big and medium-sized towns displaying a pro-PO orientation (the last excluded one was Świnoujście), in the remaining part of the country Law and Justice would have been the victorious party in the 2007 elections. In turn, in the 1 st round of voting during the 2010 presidential election, the pivot of the electoral scissors in the version of the successive elimination of towns favouring Komorowski was the 16 th town in the new ranking, namely Gliwice, and in the 2 nd round of voting - the $15 \mathrm{th}$, which was Torun. Those were the same towns as in the classical elimination version, because among towns preceding Gliwice and Toruń in size ranking was one favouring Kaczyński, viz. Lublin, not taken into account in this version of the analysis. The shape of the scissors in both the classical and the modified version in the 2 nd round of voting is presented in Fig. 3. The curves illustrating changes in support for the candidates in the 2 nd round, determined by selective elimination of only those towns in which the electorate was in favour of Komorowski, show an even wider opening of the scissors than in the traditional version. In turn, differences between the blades of the scissors in the traditional version and in the selective elimination of towns can be a measure of elasticity of the electorate of the towns under study (in relation to the averaged tendency in the traditional version) 

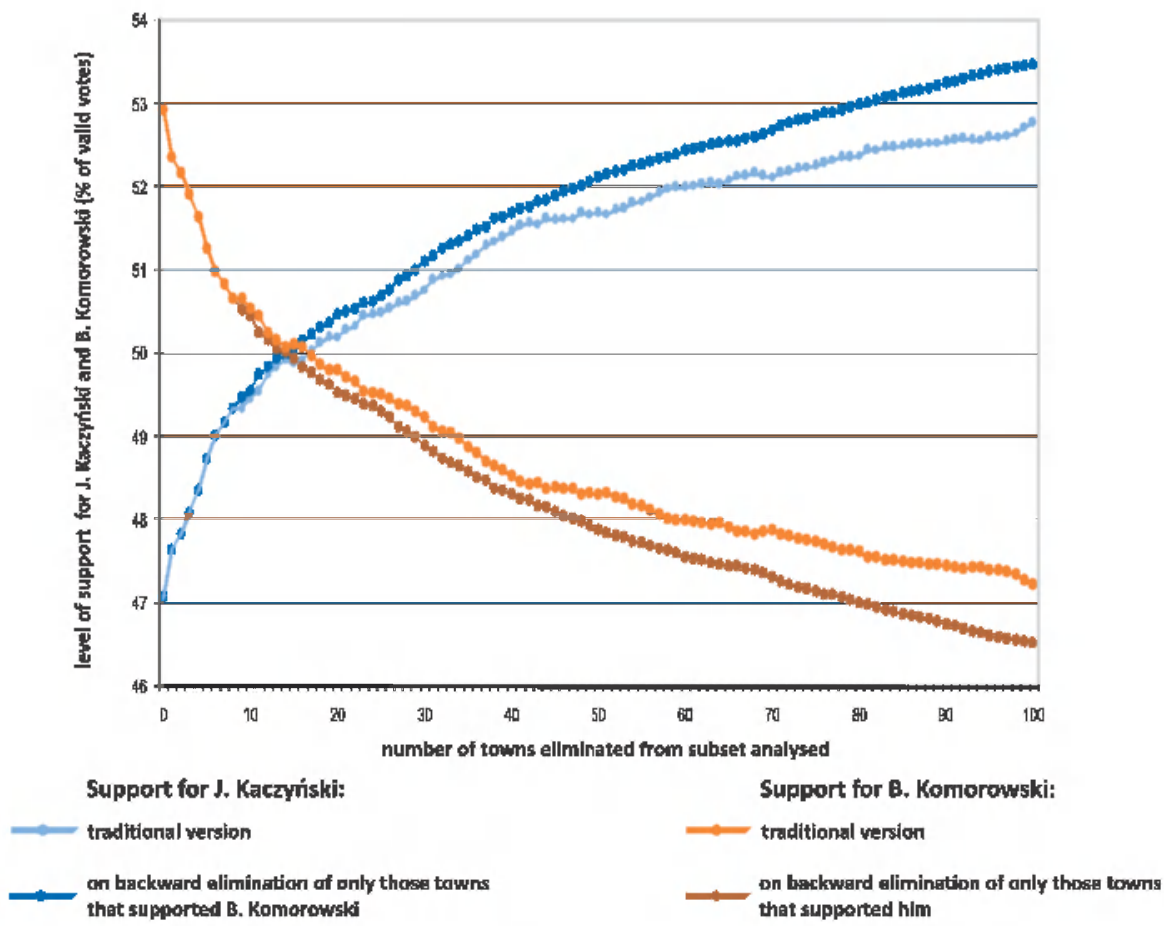

Figure 3. Electoral scissors in the 2 nd round of the 2010 presidential election:

in the traditional version (as in Fig. 1) and on elimination of towns supporting B. Komorowski

and can be used to measure fluctuations in voter alignment.

\section{ELECTORAL TYPES OF TOWNS}

The electoral types of towns can be distinguished by analysing basic indices characterising the voting behaviour of the population. The research embraced 131 Polish towns with the highest population figures (as of December 2009); they accounted for $42.0 \%$ of the total population.

The simplest analysis was presented in the preceding section: use was made of the simple index of above-average (or belowaverage) support for a leading party, and two sub-types were distinguished: towns with a pro-PiS electorate (or giving aboveaverage support to Kaczyński in the presidential election), and pro-PO towns (in favour of Komorowski). Among the 131 towns, in the 2010 presidential election four towns with over 100,000 population (out of 39 in this size group) displayed an above-average support for Kaczyński; apart from them, this was the tendency recorded in the 1 st round of voting in Ruda Śląska, and in the 2nd round-in Płock. A similar tendency was shown by the electorate of 18 towns with a population of 50-100 thousand (out of 47 towns in this size group), but in Starachowice this only concerned the 1st round, and in Pickary Śląskie, the 2 nd round (cf. Table 4).

A more complex typology can be obtained by considering the results of the three leading presidential candidates in the 1 st round of voting in the 2010 election (and by analogy the three chief parties in the Sejm elections of 2007), and employing a dichotomous division of the support for them: above the national average $(\mathrm{H})$ and below the national average $(\mathrm{L})$. In the 1st round of voting in the 2010 election, this 
Table 4. Towns with an above-average proportion of support for PiS in the 2007 Sejm election and for J. Kaczyński in the 2010 presidential election

\begin{tabular}{|c|c|c|c|}
\hline $\begin{array}{l}\text { Size of towns, } \\
\text { in thous. population } \\
\text { (as of December 2009) }\end{array}$ & 2007 Sejm election & $\begin{array}{l}2010 \text { presidential election } \\
\text { (1st round) }\end{array}$ & $\begin{array}{l}2010 \text { presidential election } \\
\text { (2nd round) }\end{array}$ \\
\hline$>200$ & $\begin{array}{l}\text { Lublin, Radom, Kielce } \\
\text { (3) }\end{array}$ & $\begin{array}{l}\text { Lublin, Radom } \\
\text { (2) }\end{array}$ & $\begin{array}{l}\text { Lublin, Radom } \\
\text { (2) }\end{array}$ \\
\hline $100-200$ & $\begin{array}{l}\text { Rzeszów, Ruda S1., Tarnów } \\
\text { (3) }\end{array}$ & $\begin{array}{l}\text { Rzeszów, Ruda Ś1., Tarnów } \\
\text { (3) }\end{array}$ & $\begin{array}{l}\text { Rzeszów, Płock, Tarnów } \\
\text { (3) }\end{array}$ \\
\hline $50-100$ & $\begin{array}{l}\text { Jastrzębie Zdrój, Nowy } \\
\text { Sącz, Piotrków Tryb., } \\
\text { Siedlce, Myslowice, Lubin, } \\
\text { Ostrowiec Świętokrzyski, } \\
\text { Suwałki, Chelm, Zamośc, } \\
\text { Przemyśl. Tomaszów Maz., } \\
\text { Stalowa Wola, Łomża, Żory, } \\
\text { Bełchatów, Mielec, Piekary } \\
\text { Śl., Biala Podl., Ostrolęka, } \\
\text { Starachowice } \\
\text { (21) }\end{array}$ & $\begin{array}{l}\text { Jastrzębie Zdrój, Nowy Sącz, } \\
\text { Piotrków Tryb., Siedlce, Lubin, } \\
\text { Ostrowiec Świętokrzyski, } \\
\text { Glogów, Chelm, Zamość, } \\
\text { Przemyśl. Tomaszów Maz., } \\
\text { Stalowa Wola, Łomża, } \\
\text { Belchatów, Mielec, Biała } \\
\text { Podl., Ostrolęka, Starachowice } \\
\text { (18) }\end{array}$ & $\begin{array}{l}\text { Jastrzębie Zdrój, Nowy Sącz, } \\
\text { Piotrków Tryb., Siedlce, Lubin, } \\
\text { Ostrowiec Swiętokrzyski, } \\
\text { Glogów, Chelm, Zamośc, } \\
\text { Przemyśl, Tomaszów Maz., } \\
\text { Stalowa Wola, Lomża, } \\
\text { Belchatów, Mielec, Piekary S1. } \\
\text { Biala Podl., Ostrolęka } \\
\text { (18) }\end{array}$ \\
\hline $35-50$ & $\begin{array}{l}\text { Tarnobrzeg, Puławy, } \\
\text { Radomsko, Skarżysko- } \\
\text { Kamienna, Krosno, Dębica, } \\
\text { Kutno, Ciechanów, Otwock, } \\
\text { Zduńska Wola, Sieradz, } \\
\text { Jaroslaw, Swidnik, Sanok, } \\
\text { Knurów, Sochaczew, Jaslo, } \\
\text { Olkusz, Wołomin, Kraśnik } \\
\text { (20) }\end{array}$ & $\begin{array}{l}\text { Tarnobrzeg, Puławy, } \\
\text { Radomsko, Skarżysko- } \\
\text { Kamienna, Krosno, Dębica, } \\
\text { Kutno, Ciechanów, Otwock, } \\
\text { Zduńska Wola, Sieradz, } \\
\text { Jaroslaw, Świdnik, Sanok, } \\
\text { Knurów, Sochaczew, Jaslo, } \\
\text { Olkusz, Wolomin, Kraśnik } \\
\text { (20) }\end{array}$ & $\begin{array}{l}\text { Wodzisław Śl., Pulawy, } \\
\text { Radomsko, Skarżysko- } \\
\text { Kamienna, Krosno, Dębica, } \\
\text { Kutno, Ciechanów, Otwock, } \\
\text { Zduńska Wola, Sieradz, } \\
\text { Jaroslaw, Świdnik, Sanok, } \\
\text { Knurów, Sochaczew, Jaslo, } \\
\text { Olkusz, Wolomin, Kraśnik } \\
\text { (20) }\end{array}$ \\
\hline
\end{tabular}

Source: own calculations on the basis of the State Electorl Committee.

was the sequence of candidates: Bronislaw Komorowski (average support at the scale of the country, without the returns from abroad, $41.47 \%$ of valid votes) - Jaroslaw Kaczyński (36.46\%)-Grzegorz Napiera1ski $(13.75 \%)$, and in the 2 nd round, only the sequence of the two main contenders: Komorowski $(52.92 \%)$-Kaczyński $(47.08 \%)$. In turn, in the 2007 parliamentary elections this was the sequence of the three main parties whose members were those presidential candidates, respectively: the Civic Platform $(41.36 \%)$ - Law and Justice (32.13\%) - the Left and the Democrats (LiD) $(13.20 \%)^{1}$. The towns in which the mentioned candidates captured above-average support were placed in class H. Thus, the sequence HLL,

1 The core of the conglomerate known as the Left and the Democrats was the Democratic Left Alliance, whose leader and candidate for president in 2010 was Grzegorz Napieralski. for example, denotes above-average support for Komorowski or the Civic Platform (the first symbol in the sequence), and belowaverage support for both Kaczyński (the second symbol) and Napieralski (the third symbol).

A rather curious electoral type, $\mathrm{HHH}$, was recorded in Ruda Śląska, where all three leading contenders won more than average support, which was possible because of the poor showing of the remaining seven candidates in that town. Equally rare was the type HHL (high level of support for the two chief rivals), which appeared in Tarnow, Pickary Śląskie and Wodzisław Śląski (Fig. 4). In turn, as many as 54 towns were classed as type HLH (above-average support for Komorowski and Napieralski), and 28 towns, as type HLL (stronger support for Komorowski only). This last type included the biggest towns in Poland: Warsaw, Cracow, Wroclaw, 
Poznań, and Gdańsk. Type LHL, with stronger support for Kaczyński only, embraced 19 towns in the 1st round of voting, including Lublin, Radom, Rzeszów, Nowy Sącz, Przemyśl, Stalowa Wola and Łomża, while 18 towns belonged to type $\mathrm{LHH}$ (above-average support for Kaczyński and Napieralski). In 8 towns (Konin, Ostrowiec Świętokrzyski, Glogów, Starachowice, Skierniewice, Sieradz, Knurów, Mińsk Mazowiecki) above-average support was only given to the left-wing candidate, Napieralski (Fig. 4).
On the basis of the average national support for the three leading presidential contenders in the 1st round of voting, seven types of towns were distinguished by the criterion of above-average $(\mathrm{H})$ or belowaverage (L) support. The same classification can be made on the basis of the 2007 Sejm elections, and the 2nd round of the presidential ballot (but in this case only two types can be observed: HL-above-average support for Komorowski, or LH-aboveaverage support for Kaczyński). When comparing the types of towns distinguished on

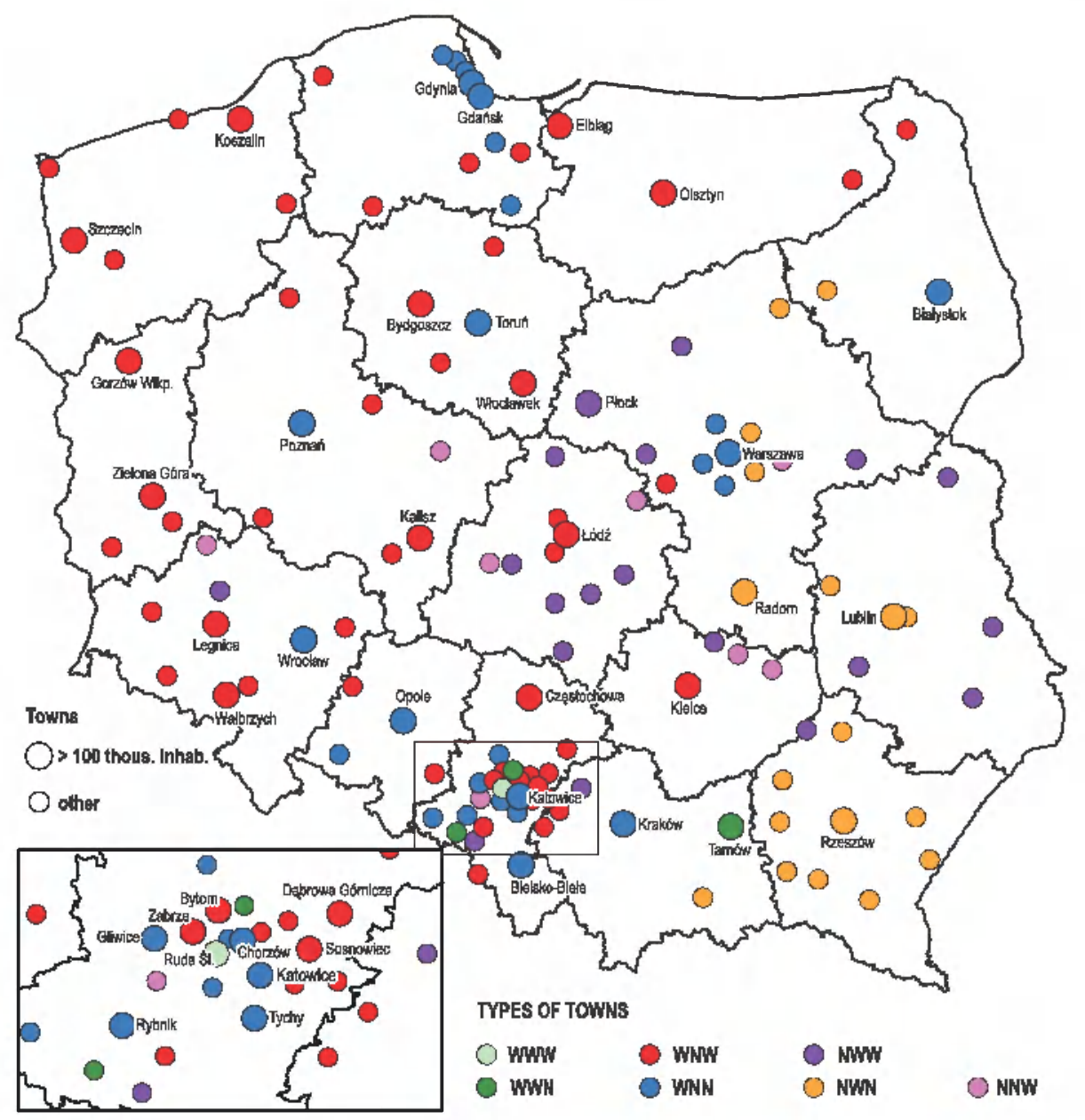

Figure 4. Types of Polish towns determined on the basis of an above-average support for the three leading presidential contenders in the 1st round of the 2010 election 
the basis of the 2007 Sejm elections and the 2010 presidential ballot, one can observe that in as many as 92 towns (out of the 131 analysed) the voter alignment was stable. The most usual sequence was HLH (2007) $>\mathrm{HLH}(2010,1$ st round of voting) $>\mathrm{HL}$ ( 2 nd round). To this type, displaying aboveaverage support for Komorowski (and the Civic Platform) and Napieralski (and the Left), belonged 47 towns, including Łódź, Szczecin, Bydgoszcz, Częstochowa, Sosnowiec, Zabrze, Bytom, Olsztyn, Dąbrowa Górnicza, and Elbląg. In turn, 20 towns formed a sequence HLL $>$ HLL $>\mathrm{HL}$ (with above-average support for Komorowski or PO only), and this group embraced Cracow, Wroclaw, Gdańsk, Katowice, Gdynia, Bielsko-Biala, Tychy, and Chorzów. The electorate of 11 towns was steadily for Kaczyński (and PiS), which was reflected in the sequence of types: LHL > LHL > LH. Those were Lublin, Radom, Nowy Sącz, Stalowa Wola, Mielec, Ostrołęka, Puławy, Dębica, Jarosław, Swidnik, and Jasło. The sequence LHH > LHH > LH, indicative of above-average support for Kaczyński (and PiS) and Napieralski (and the Left and the Democrats in 2007), and in consequence the success of the former candidate in the 2 nd round, was observed in 12 towns (including Jastrzębie Zdrój, Piotrków Trybunalski, Siedlce, Lubin, and Bełchatów). The last of the stable, permanent sequences was that of LLH > LLH > LH (with above-average support for the Left and its candidate, and in the 2 nd round supporting Kaczyński), recorded in two towns: Glogów and Sieradz.

In the years 2007-2010, the group of towns with a volatile electorate included 39 towns, and the most popular sequence here was a transition from type HLH in 2007 (above-average support for PO and $\mathrm{LiD})$ to HLL in the 1 st round of voting in the 2010 election (above-average support for Komorowski) and HL in the 2nd round of voting (success again of the 1st-round winner). This was the sequence exhibited by 7 towns (Warsaw, Poznań, Białystok, Toruń, Gliwice, Opole, and Kwidzyn). Another interesting sequence of variable choices could be noted in two towns of Subcarpathia (Przemyśl and Krosno) and two towns close to the state capital (Otwock and Wołomin), where in 2007 the electorate supported the idea of a PO-PiS combination (type HHL), but in the 2010 election it opted for Kaczyński, with type LHL in the 1st round and $\mathrm{LH}$ in the 2 nd round.

To obtain a synthetic picture of the structure of voter alignment and identify towns with a similar political orientation in the 2010 presidential election, use was made of principal components analysis derived from a correlation matrix. Taken into consideration was the level of support for: (1) Marek Jurek, (2) Kaczyński in the 1st round of voting, (3) Komorowski in the 1st round of voting, (4) Komorowski in the 2nd round of voting, (5) Janusz Korwin-Mikke, (6) Grzegorz Napieralski, (7) Andrzej Olechowski, and (8) combined support for Waldemar Pawlak and Andrzej Lepper. Excluded from the analysis were the votes cast for the two weakest candidates (Kornel Morawiecki and Bogusław Ziętek) and those for Kaczyński in the 2nd round of voting (because they complemented the support for his rival), while adding up the votes for two contenders especially popular with the rural and small-town electorate but marginalised in big cities (even though the candidates themselves treated each other as rivals in those environments).

Thus, the dimension of the observation matrix was 131 towns $x 8$ variables. After the transformation of the variables into principal components, the first of them accounted for $43.19 \%$ of the variance of the original variables, and the second, for $30.27 \%$.

The first component $\left(V_{1}\right)$ showed a statistically significant correlation $(\alpha=0.05)$ with five variables: (1) support for Komorowski in the 2 nd round of voting $(r=+0.973)$, (2) support for Komorowski in the 1st round of voting $(r=+0.972)$, (3) support for Olechowski ( $\mathrm{r}=+0.499)$, (4) support for Kaczyński $(r=-0.951)$, and (5) joint support for Pawlak and Lepper $(r=+0.550)$. This component can be interpreted-despite its significant 
correlation with the five original variablesas primarily that of rivalry between the two chief presidential contenders and of an electorate interested in modernisation programmes. The highest values of the first component were obtained for Sopot (3.61), Poznań (3.49), Opole (3.28), Gdynia (3.26), Gdańsk (2.81), Zielona Góra (2.72), Gliwice (2.58), and Kwidzyn (2.33). The lowest figures were obtained for towns of eastern and central Poland with electorates strongly in favour of Kaczyński: Bełchatów (-4.61), Kraśnik (-4.49), Jarosław (-3.88), Dębica (-3.11), Siedlce (-3.08), Zamość (-2.96), Ciechanów (-2.95), and Stalowa Wola $(-2.90)$.

In turn, the second component $\left(V_{2}\right)$ was most strongly correlated with the following original variables: (1) support for Napieralski $(r=+0.834)$, (2) combined support for Pawlak and Lepper $(r=+0.515)$, (3) support for Korwin-Mikke $(r=-0.715)$, (4) support for Jurek $(r=-0.689)$, and (5) support for Olechowski $(r=-0.632)$. This component can be treated as a measure of opposition between an electorate interested in left-wing and populist programmes and ones demanding alternative programmes: a radical socio-economic change or a society conservative in its socio-religious life. The highest values of the second principal component were characteristic of Inowrocław (3.67), Włocławek (3.05), Kutno (3.00), Ostrowiec Świętokrzyski (2.96), Zawiercie (2.69), Konin (2.55), and Ciechanów (2.42). In turn, the lowest values were obtained for Cracow (-4.24), Sopot (-3.18), Rzeszów (-2.87), Rumia (-2.73), Lublin (-2.62), Wroclaw (-2.58), Piaseczno (-2.48), and Warsaw (-2.43).

The values of the first component were divided into three classes: H-representing strong support for Komorowski and openness to modernisation $\left(V_{1}>+0.75\right)$; $\mathrm{M}-$ denoting similar support for the two leading presidential contenders and neutrality towards changes $\left(+0.75<V_{1}>-0.75\right)$, and L-of strong support for Kaczyński and a deep attachment to tradition $\left(V_{1}<-0.75\right)$. In turn, the values of the second component $\left(V_{2}>0.00\right.$ and $\left.V_{2}<0.00\right)$ were divided into two classes. On the basis of the distribution of the first component $V_{1}$, three basic subtypes of towns were distinguished $(\mathrm{A}-$ with high values of the component; $\mathrm{B}$ - with medium values; and $\mathrm{C}$-with low values), and within each, a further two sub-types based on the distribution of the second component $V_{2}(1-$ with high values of the component; and 2 -with low values). The distribution of the six types of towns is presented in Fig. 5.

\section{MODEL OF THE VOTE TRANSFER AND ELECTORAL ACTIVITY IN THE 2ND ROUND OF VOTING}

An interesting model of shifts in voting and the turnout in the 2 nd round of the 2005 presidential election on the basis of correlations among electoral indices from the 1 st round in terms of the urban /rural subsystem was presented by Śleszyński (2007b). His assumptions were used to forecast voter alignment in the 2 nd round of the 2010 presidential election, but only with reference to the 131 big and medium-sized towns analysed.

In accordance with Śleszyński's model, the first step involved calculating linear correlation coefficients (Table 5). In the 1 st round, support for Kaczyński in the 131 towns co-occurred with that for KorwinMikke, Jurek and Pawlak. In turn, correlation coefficients were positive in the case of support for Komorowski and Olechowski, and to a lesser extent for Morawiecki. The next step was finding a dependence between the transfer of votes from the individual 1 stround candidates to the 2 nd-round contenders and the strength of co-occurrence of support for them with the voter turnout. Finally, weights were determined to characterise the scale of the probable transfers of votes in the 2 nd round of voting (Table 6) and the anticipated returns for the two 2 nd-round candidates in the particular towns were calculated.

As it turned out, the results of the 2 nd round of voting in the 2010 presidential election anticipated by the model proved to be 


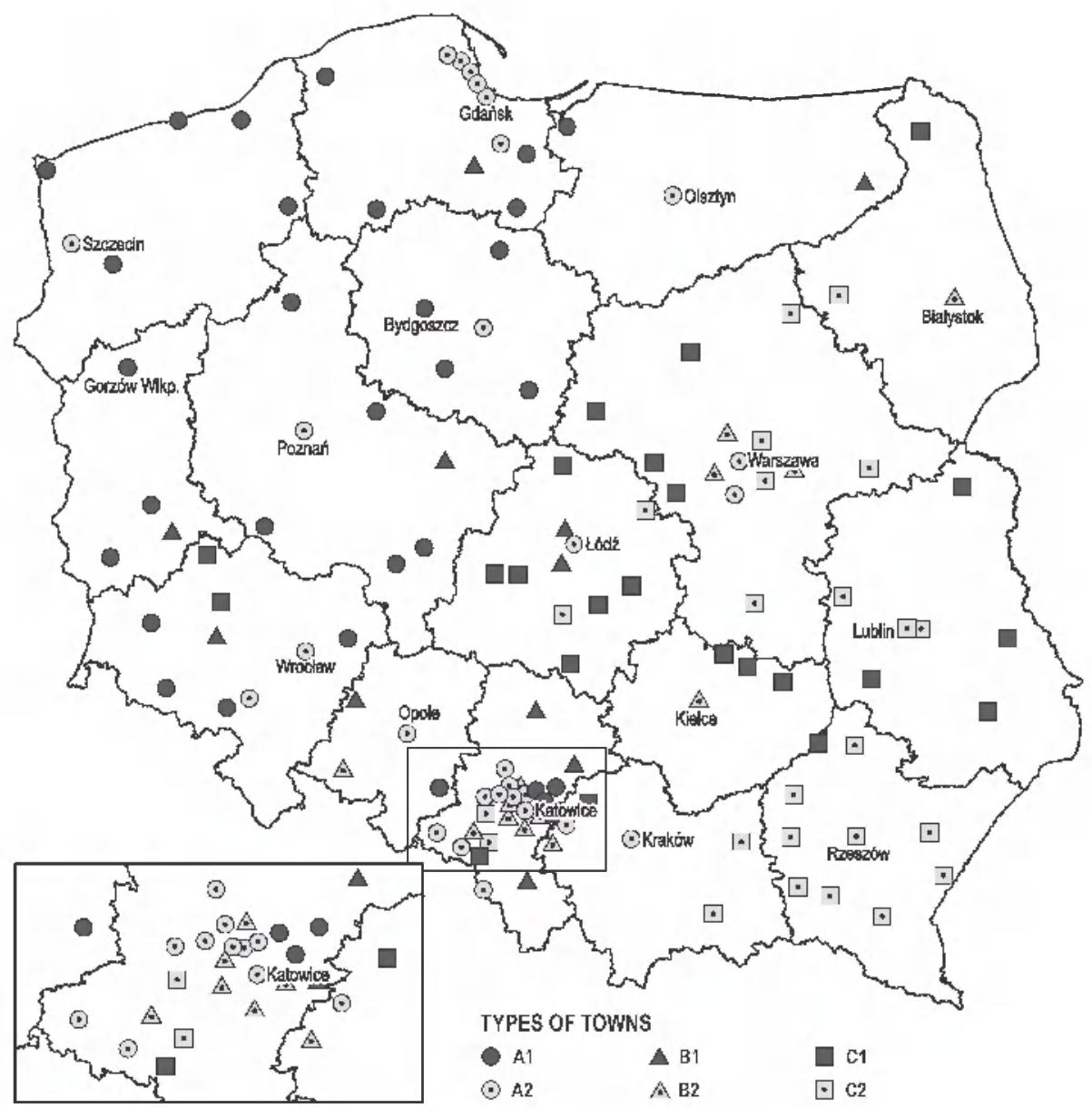

Figure 5. Types of Polish towns determined on the basis of the distribution of values of the first two principal components characterising the 1 st and 2 nd rounds of the 2010 presidential election

clearly overestimated when compared with the real-life ones, especially in the biggest of the 131 towns (Table 7). This may largely have been due to the holiday departures of their residents at the start of July 2010. For example, in Warsaw the number of voters in the 2 nd round was overestimated by 90,000 , while in several seaside resorts the actual voter turnout was higher than anticipated (e.g. in Gdynia by 3,400; in Sopot by 3,200; and in Kolobrzeg by 2,800). Still, the model worked out by Śleszyński (2007b) proved highly effective in forecasting both, the 2 nd-round winner and the voter align- ment for the two candidates in the individual town-size groups.

\section{EFFECT OF THE SUB-SYSTEM OF BIG AND MEDIUM-SIZED TOWNS ON ELECTION RESULTS AT THE REGIONAL SCALE}

In earlier analyses of the electoral behaviour of the Polish population after the sociopolitical changes of 1989 , regional differences were studied in terms of both, electoral participation and the choice of a political option (cf. Węclawowicz 1993, 1995; Bartkows- 
Table 5. Level of support for and correlations of the winners of the 1st round of voting with all the candidates in the 2010 presidential election in a set of 131 big and larger medium-sized towns

\begin{tabular}{llllc}
\hline \multirow{2}{*}{ Presidential candidate } & \multirow{2}{*}{$\begin{array}{l}\text { Support in 1st-round } \\
\text { of voting }(\%)\end{array}$} & \multicolumn{4}{l}{ Coefficient of correlation } \\
\cline { 3 - 5 } & 47.97 & 1.0000 & -0.9345 & voter turnout \\
\hline B. Komorowski & 31.06 & -0.9345 & 1.0000 & 0.1664 \\
J. Kaczyński & 13.63 & -0.1444 & -0.2076 & -0.0132 \\
G. Napieralski & 2.98 & -0.1383 & 0.2266 & -0.4402 \\
J. Korwin-Mikke & 1.73 & 0.4291 & -0.2948 & 0.3675 \\
A. Olechowski & 1.05 & -0.2069 & 0.3745 & 0.4949 \\
M. Jurek & 0.70 & -0.5352 & 0.4870 & 0.0666 \\
W. Pawlak & 0.55 & -0.0983 & -0.0658 & -0.0103 \\
A. Lepper & 0.18 & -01065 & -0.0374 & -0.5613 \\
B. Ziętek & 0.13 & 0.1172 & -0.1429 & -0.3615 \\
K. Morawiecki & & & & 0.0528 \\
\hline
\end{tabular}

Source: own calculations on the basis of the State Electoral Committee.

Table 6. Weights of the flow of votes in the 2 nd round of the

2010 presidential election for the set of Polish towns

\begin{tabular}{lll}
\hline & \multicolumn{2}{l}{ Weights of the flow of votes } \\
\cline { 2 - 3 } Candidate & for B. Komorowski & for J. Kaczyński \\
\hline B. Komorowski & 1.0832 & 0.0000 \\
J. Kaczyński & 0.0000 & 0.9934 \\
G. Napieralski & 0.4049 & 0.3750 \\
J. Korwin-Mikke & 0.4885 & 0.6953 \\
A. Olechowski & 0.8352 & 0.4122 \\
M. Jurek & 0.3781 & 0.6552 \\
W. Pawlak & 0.2369 & 0.7579 \\
A. Lepper & 0.3533 & 0.3661 \\
B. Ziętek & 0.3944 & 0.4228 \\
K. Morawiecki & 0.5808 & 0.4456 \\
\hline
\end{tabular}

Source: own calculations.

ki 2003; Kowalski 2003). As a rule, among the regions with an above-averảge voter turnout were the voivodeships of south-eastern Poland: Malopolska and Subcarpathia, or the former Galicia Land in the Austrian partition.

However, in the 2010 presidential election-in both rounds of voting - the highest voter turnout was noted in Mazovia (60.1\% and $60.7 \%$, respectively), and a slightly lower one, in Pomerania and Malopolska. Opole had the lowest voter turnout in both rounds, but this may have been due to the international emigration of the region's population and to its lists of eligible voters including persons permanently staying abroad (cf. Krzemiński 2009). Worth noting is also the fact that in Subcarpathia the voter turnout in the 1st round $(53.8 \%)$ was below the national average of $54.7 \%$, but in the 2 nd round the region registered an above-average figure again $55.9 \%$ as against the national mean 
Table 7. Anticipated flow of votes in the 2 nd round of the 2010 presidential election

\begin{tabular}{lcccc}
\hline \multirow{2}{*}{$\begin{array}{l}\text { Set of towns under analysis } \\
\text { (thous. population) }\end{array}$} & $\begin{array}{l}\text { Actual results } \\
\text { of 2nd round }\end{array}$ & \multicolumn{2}{l}{$\begin{array}{l}\text { Anticipated results } \\
\text { of 2nd round }\end{array}$} \\
\cline { 2 - 5 } & B. Komorowski & J. Kaczyński & B. Komorowski & J. Kaczyński \\
\hline Absolute values (thous. persons) & & 1896.5 & 3354.1 & 2058.1 \\
\hline$>100$ & 3191.3 & 614.4 & 819.4 & 631.1 \\
$50-100$ & 794.1 & 383.1 & 505.3 & 388.4 \\
$35-50$ & 497.3 & 2894.0 & 4678.8 & 3077.6 \\
all big and larger medium-sized towns & 4482.7 & & 62.0 & 38.0 \\
\hline Relative values (structure of vote in $\%)$ & & 37.3 & 56.5 & 43.5 \\
\hline$>100$ & 62.7 & 43.6 & 56.5 & 43.5 \\
$50-100$ & 56.4 & 43.5 & 60.3 & 39.7 \\
$35-50$ & 56.5 & 39.2 & & \\
\hline
\end{tabular}

Source: own calculations on the basis of the State Electoral Committee.

of $55.2 \%$ ). In that round the voter turnout increased markedly (by more than 1.5 percentage points) in Świętokrzyska Land (by 3.3 p.p.), Podlasie (3.2), Lublin (2.5), Subcarpathia (2.1), and Małopolska (1.6). Thus, the greatest mobilisation of the electorate in the decisive round occurred in those regions in which Kaczyński was the winner.

Regional differences in the voter turnout in the presidential election of 2005 were greatly influenced by a high level of electoral participation in urban agglomeration (cf. Śleszyński 2007a). That is why a comparison was made of the results of the 2010 presidential election by two types of subsystem in each voivodeship: the regional sub-system embracing big and the larger of medium-sized towns, and the one including the remaining towns and rural areas (Table 8). One of the obvious differences between the two sub-systems was that in the voter turnout. At the scale of the country, in the sub-system of big and medium-sized towns the turnout in the 1st round was 8.7 percentage points higher than in the rest-ofcountry sub-system, while in the 2 nd round the advantage persisted but was a bit less pronounced, at 6.4 p.p. At the regional scale, the highest differences in voter participation in the 2 nd round of the presidential election between the sub-system of big and mediumsized towns and the rest-of-voivodeship subsystem were in Opole (11.8 p.p.), WarmiaMazuria (9.3), Kujavia-Pomerania (8.9), and West Pomerania (8.8). The differences between the two sub-systems were small in Silesia (0.3), Subcarpathia (3.4) and Łódź (3.8), which may mean that in their case the urbanisation factor had no effect on the voting activity of the residents. The factor could be noted to have a similar selective effect on the level of support for Komorowski in the 2 nd round of voting in the two regional subsystems. It was of almost no significance in West Pomerania, where Komorowski obtained similar support in big and mediumsized towns ( $66.4 \%$ of valid votes) as in small towns and rural areas $(66.1 \%)$ (Table 8 ); the difference between the two subsystems was also slight in Warmia-Mazuria. However, in Łódź (22.4 p.p.), Mázoviá (22.0), Małopolska (21.0), Subcarpathia (20.0), Świętokrzyska Land (19.7), and Lublin (17.3) the differences in support for Komorowski between the two sub-systems were especially big. Those were voivodeships in which the winner of the 2 nd round of voting was the other presidential contenderKaczyński. In two regions, viz. Lublin and Subcarpathia, Kaczyński captured more 
Table 8. Differences in the indicators of voter turnout and support for the two chief presidential contenders in the analysed towns and the rest of their respective voivodeships in the 2010 presidential election

\begin{tabular}{|c|c|c|c|c|c|c|c|c|c|c|}
\hline \multirow[b]{3}{*}{ Voivodeship } & \multicolumn{5}{|c|}{ Big and larger medium-sized towns in voivodeship } & \multicolumn{5}{|c|}{ Rest of voivodeship } \\
\hline & \multicolumn{5}{|c|}{ basic electoral indicators $(\%)$} & \multicolumn{5}{|c|}{ basic electoral indicators $(\%)$} \\
\hline & $\begin{array}{l}\text { voter turnout } \\
\text { in } 1 \text { st round }\end{array}$ & $\begin{array}{l}\text { fvoter turnout } \\
\text { in } 2 \text { nd round }\end{array}$ & $\begin{array}{l}\text { support for } \\
\text { J. Kaczyński } \\
\text { in 1st round }\end{array}$ & $\begin{array}{l}\text { support for } \\
\text { B. Komoro- } \\
\text { wski in } \\
\text { 1st round }\end{array}$ & $\begin{array}{l}\text { support for } \\
\text { B. Komoro- } \\
\text { wski in } 2 \\
\text { nd round }\end{array}$ & $\begin{array}{l}\text { fvoter turnout } \\
\text { in } 1 \text { st round }\end{array}$ & $\begin{array}{l}\text { voter turnout } \\
\text { in } 2 \text { nd round }\end{array}$ & $\begin{array}{l}\text { support for } \\
\text { J. Kaczyński } \\
\text { 1st round }\end{array}$ & $\begin{array}{l}\text { support for } \\
\text { B. Komoro- } \\
\text { wski in } \\
\text { 1st round }\end{array}$ & $\begin{array}{l}\text { support for } \\
\text { B. Komoro- } \\
\text { wski in } \\
\text { 2nd round }\end{array}$ \\
\hline Dolnośląskie & 58.80 & 57.53 & 29.43 & 49.77 & 62.84 & 49.76 & 49.43 & 32.13 & 45.14 & 57.76 \\
\hline Kujawsko-pomorskie & 58.31 & 56.58 & 26.75 & 50.41 & 65.52 & 48.30 & 47.64 & 30.44 & 41.87 & 56.50 \\
\hline Lubelskie & 58.81 & 58.86 & 41.25 & 37.32 & 48.79 & 49.27 & 52.88 & 52.73 & 22.52 & 31.47 \\
\hline Lubuskie & 56.95 & 55.29 & 25.07 & 52.74 & 68.11 & 47.83 & 46.76 & 25.34 & 50.17 & 65.94 \\
\hline Łódzkie & 59.18 & 57.86 & 32.65 & 44.70 & 57.94 & 52.10 & 54.07 & 48.25 & 25.81 & 35.59 \\
\hline Małopolskie & 62.27 & 61.98 & 34.17 & 46.39 & 57.77 & 55.11 & 57.61 & 52.18 & 29.26 & 36.75 \\
\hline Mazowieckie & 66.01 & 64.68 & 33.11 & 47.79 & 59.12 & 54.30 & 56.98 & 49.84 & 28.86 & 37.11 \\
\hline Opolskie & 56.17 & 55.36 & 24.36 & 54.00 & 68.56 & 43.15 & 43.58 & 27.75 & 50.50 & 62.83 \\
\hline Podkarpackie & 57.64 & 58.30 & 42.21 & 37.20 & 48.57 & 52.13 & 54.88 & 59.79 & 21.66 & 28.57 \\
\hline Podlaskie & 57.50 & 58.64 & 36.71 & 43.27 & 55.77 & 48.56 & 52.82 & 47.84 & 31.94 & 43.16 \\
\hline Pomorskie & 62.60 & 62.72 & 26.67 & 55.93 & 67.98 & 52.63 & 54.40 & 30.67 & 48.40 & 60.77 \\
\hline Śląskie & 55.57 & 54.40 & 30.10 & 47.49 & 60.53 & 53.69 & 54.07 & 37.32 & 40.46 & 51.46 \\
\hline Świętokrzyskie & 56.36 & 57.52 & 35.69 & 39.94 & 53.80 & 46.58 & 50.87 & 49.03 & 24.18 & 34.10 \\
\hline Wărmińs̄kōo-mãzurs̄kiè & 57.63 & 56.79 & 28.13 & 50.27 & 64.38 & 46.19 & 47.53 & 28.37 & 46.93 & 61.52 \\
\hline Wielkopolskie & 62.53 & 60.37 & 24.44 & 54.66 & 68.39 & 53.11 & 51.74 & 30.39 & 43.10 & 56.63 \\
\hline $\begin{array}{l}\text { Zachodnio } \\
\text { pomorskie }\end{array}$ & 58.88 & 57.51 & 25.78 & 50.35 & 66.44 & 48.04 & 48.71 & 24.27 & 49.67 & 66.11 \\
\hline
\end{tabular}

Source: own calculations on the basis of the State Electoral Committee. 
Table 9. Model sequences of behaviour of the electorates of the 131 biggest towns in Poland in the 2007 and 2010 elections (sequence above (+) or below (-) mean national support for chief parties and presidential candidates in 2007 and 2010 elections)

\begin{tabular}{|c|c|c|c|c|c|c|c|c|}
\hline \multicolumn{3}{|c|}{$\begin{array}{l}2007 \\
\text { Sejm election }\end{array}$} & \multicolumn{3}{|c|}{$\begin{array}{l}2010 \\
\text { presidential } \\
\text { election } \\
\text { (1st round) }\end{array}$} & \multicolumn{2}{|c|}{$\begin{array}{l}2010 \\
\text { presidential } \\
\text { election } \\
\text { (2nd round) }\end{array}$} & \multirow[b]{2}{*}{ Towns belonging to given type of sequence } \\
\hline$\cong$ & क & $\mathrm{A}$ & 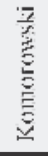 & 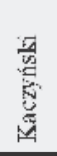 & 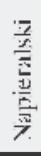 & 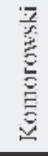 & 氙 & \\
\hline \multirow[t]{2}{*}{+} & - & - & + & - & - & + & - & $\begin{array}{l}\text { Kraków, Wroclaw, Gdańsk, Katowice, Gdynia, Bielsko-Biala, } \\
\text { Tychy, Chorzów, Tarnowskie Góry, Tczew, Pruszków, Racibórz, } \\
\text { Swiętochlowice, Legionowo, Wejherowo, Nysa, Rumia, Piaseczno, } \\
\text { Mikołów, Sopot }\end{array}$ \\
\hline & & & + & - & + & & & Żyrardów \\
\hline \multirow[t]{4}{*}{+} & - & + & + & - & + & + & - & $\begin{array}{l}\text { Lódź, Szczecin, Bydgoszcz, Częstochowa, Sosnowiec, } \\
\text { Zabrze, Bytom, Olsztyn, Dąbrowa Górnicza, Elbląg, Gorzów } \\
\text { Wielkopolski, Wałbrzych, Zielona Góra, Wloclawek, Kalisz, } \\
\text { Koszalin, Legnica, Grudziądz, Slupsk, Jaworzno, Jelenia Góra, } \\
\text { Inowrocław, Pila, Ostrów Wielkopolski, Siemianowice Śląskie, } \\
\text { Stargard Szczecinski, Gniezno, Pabianice, Kędzierzyn-Koźle, } \\
\text { Leszno, Świdnica, Będzin, Zgierz, Ełk, Zawiercie, Kolobrzeg, } \\
\text { Świnoujście, Oświęcim, Boleslawiec, Nowa Sól, Chojnice, } \\
\text { Chrzanów, Żary, Malbork, Szczecinek, Oleśnica, Cieszyn }\end{array}$ \\
\hline & & & + & - & - & & & Warszawa, Poznań, Białystok, Toruń, Gliwice, Opole, Kwidzyn \\
\hline & & & - & + & + & & & Plock \\
\hline & & & - & - & + & & & Konin, Skierniewice \\
\hline \multirow[t]{2}{*}{+} & - & - & + & - & + & & & Brzeg \\
\hline & & & - & - & + & & & Mińsk Mazowiecki \\
\hline \multirow[t]{2}{*}{+} & + & - & + & - & - & & & Rybnik \\
\hline & & & + & - & + & & & Starogard Gdański \\
\hline+ & + & + & + & - & + & & & Żory \\
\hline \multirow[t]{3}{*}{-} & + & + & + & - & + & + & - & Kielce, Myslowice, Suwałki \\
\hline & & & - & + & + & & & Tarnobrzeg \\
\hline & & & - & - & + & & & Starachowice \\
\hline+ & + & - & + & + & - & - & + & Piekary Śląskie, Wodzisław Śląski \\
\hline \multirow[t]{2}{*}{+} & + & + & & & & & & Tarnów \\
\hline & & & - & - & + & & & Knurów \\
\hline \multirow[t]{2}{*}{+} & + & - & + & + & + & & & Ruda Śląska \\
\hline & & & - & + & - & & & Przemyśl, Krosno, Otwock, Wolomin \\
\hline- & + & - & - & + & - & - & + & $\begin{array}{l}\text { Lublin, Radom, Nowy Sącz, Stalowa Wola, Mielec, Ostrolęka, } \\
\text { Pulawy, Dębica, Jaroslaw, Swidnik, Jaslo }\end{array}$ \\
\hline - & + & - & - & + & + & - & + & Biala Podlaska, Sochaczew, Kraśnik \\
\hline - & + & + & - & + & - & - & + & Rzeszów, Łomża, Sanok \\
\hline \multirow[t]{2}{*}{ - } & + & + & - & + & + & - & + & $\begin{array}{l}\text { Jastrzębie-Zdrój, Piotrków Trybunalski, Siedlce, Lubin, Zamość, } \\
\text { Tomaszów Mazowiecki, Bełchatów, Radomsko, Skarżysko- } \\
\text { Kamienna, Kutno, Zduńska Wola, Olkusz }\end{array}$ \\
\hline & & & - & - & + & & & Ostrowiec Swiętokrzyski \\
\hline \multirow[t]{2}{*}{-} & - & + & - & + & + & - & + & Chełm, Ciechanów \\
\hline & & & - & - & + & & & Glogów, Sieradz \\
\hline
\end{tabular}

Source: own calculations. 
than half of valid votes in both sub-systems, while in the remaining four he owed his success to the particularly strong support in the sub-system of small towns and rural areas, because in big and medium-sized towns it was Komorowski who won.

\section{SUMMING UP}

The research has shown that a decisive influence on the results of the 2010 presidential election at the scale of the entire country was exerted by big cities (over 100,000 population). Worth noting is the fact that the 'blade of the electoral scissors' was much shortened in the 1st round of voting in the 2010 election (to 18 towns) when compared with the Sejm elections of 2007 (when the 'blade' eliminated as many as 93 towns). In the 1 st round the pivot of the scissors was Gliwice, and in the 2 nd round, Torun. The scissors effect can be a signal for the two rival parties to work out a strategy of political action among the electorate in the future elections. The next ballots may end in a failure of the Civic Platform if the voter turnout declines even slightly or support for this party in big towns slumps, and in success of Law and Justice in the case of further mobilisation of the electorate in small towns and rural areas (with the exception of West Pomerania, Warmia-Mazuria and Lubuska Land, where there were no marked differences in support between the sub-systems analysed).

The three ways of analysing the structure of support for the presidential contenders produced-obviously-somewhat different divisions of towns into types, but in essence the results are similar. The electorate favouring Jarosław Kaczyński (and in the 2007 Sejm election, his party Law and Justice) predominated in all the analysed towns of Subcarpathia (9) and Lublin voivodeships (7). In other regions in which Kaczyński won, some of the towns displayed a similar voter alignment as those two voivodeships, but their capitals (Warsaw, Lódź, Cracow, Białystok, Kielce) were in favour of Bronisław Komorowski. In turn, in those voivodeships where Komorowski was victorious there were towns-even though sporadically-with an electorate backing Kaczyński. Those exceptions included two Lower Silesian towns of Glogów and Lubin as well as some towns of Silesia (e.g. Jastrzębie Zdrój, Piekary Śląskie).

\section{REFERENCES}

Anduiza-Perea, E. (1999), Individuos o sistemas? Las razones de la abstencion en Europa Occidental, Centro de Investigaciones Sociologicas, Madrid.

Bartkowski, J. (2003), Tradycja i polityka. Wplyw tradycji kulturowych polskich regionów na wspólczesne zachowania spoteczne $i$ polityc$z n e$ [Tradition and politics. Effect of cultural traditions of Polish regions on contemporary social and political behaviour patterns], Wydawnictwo Akademickie Żak, Warszawa.

Chojnicki, Z. (1998), Uwarunkowania rozwoju regionu nadgranicznego-koncepcje i założenia teoretyczne [Determinants of development of a border region: Conceptions and theoretical assumptions], in Gruchman B. and Parysek J.J. (eds.), Studia rozwoju $i$ zagospodarowania przestrzennego [Studies on development and spatial organization], Wydawnictwo Akademii Ekonomicznej, Poznań, 11-48.

Chojnicki, Z., Czyż, T. (1978), Podstawy metodologiczne zastosowania analizy czynnikowej [Methodological foundations of factor analysis application], in Chojnicki, Z., Czyż, T., Parysek, J.J. and Ratajczak, W. (eds.), Badania przestrzennej struktury spotecznoekonomicznej Polski metodami czynnikowymi [Investigation of Poland's spatial socio-economic structure by means of factor methods], Oddział PAN w Poznaniu, Seria Geografia, vol. 2, PWN, Warszawa-Poznań, 7-19.

Cześnik, M. (2007), Partycypacja wyborcza w Polsce. Perspektywa porównawcza [Electoral participation in Poland. A comparative perspective], Instytut Studiów Politycznych PAN, Wydawnictwo Naukowe Scholar, Warszawa. 
Dogan, M. (1967), Political cleavage and social stratification in France and Italy, in Lipset, S.M., Rokkan, S. (eds.), Party systems and voter alignments, The Free Press, New York, 129-195.

Florczyk, A., Najdowski, T. and Żukowski, T. (1989), Nowa geografia polityczna Polski [The new political geography of Poland], $T y$ godnik Solidarność, 6 (43), 6 July.

Heffner, K. (2008), Funkcjonowanie miast malych w systemie osadniczym Polski w perspektywie $2033 r$. [Operation of small towns in the settlement system of Poland: A 2033 forecast], <www.mrr.gov.pl/rozwoj_regionalny/poziom_krajowy/polska_polityka_przestrzenna/ prace_nad_KPZK_2008-2033/Documents/ Heffner.pdf $>$, Ministry of Regional Development website, accessed 2 September 2010.

$<$ http://prezydent2010.pkw.gov.pl/PZT/PL/ WYN/W/index.htm (State Election Commission-Results of the 2010 presidential election >; 22 June to 10 July 2010).

$<$ http://www.stat.gov.pl/bdr_n/app/dane podgrup.wymiary?p_kate $=38$ p_grup $=78$ pgru $=13368 \mathrm{p}-$ dane $=0>$, (Central Statistical Office, Regional Data Bank: Population 21 June-1 July 2010).

Kowalski, M. (2003), Polaryzacja zachowań wyborczych w Polsce jako rezultat cywilizacyjnego rozdarcia kraju [Polarisation of voting behaviour in Poland as a result of the country's civilisational split], in Kowalski, M. (ed.), Przestrzeń wyborcza Polski, Instytut Geografii i Przestrzennego Zagospodarowania PAN, Warszawa, 11-48.

Krzemiński, P. (2009), Zachowania wyborcze w wyborach parlamentarnych i prezydenckich w Polsce w latach 2005-2007-wzory przestrzennych zróżnicowań [Voting behaviour in parliamentary and presidential elections in Poland in 2005-2007: Patterns of spatial diversities], Przeglad Geograficzny, 81, 2: 259-281.

Matykowski, R. (2007), Zróżnicowanie regionalne wyników wyborów do Sejmu w Polsce w latach 1991-2005 [Regional differences in the results of parliamentary elections in Poland in the years 1991-2005], in Kiniorska, I. and Sala, S. (eds.), Rola geografii spolecznoekonomicznej w badaniach regionalnych [Role of socio-economic geography in regional studies], II, Instytut Geografii Akademii Świętokrzyskiej, Kielce, 185-191.

Matykowski, R. (2010), The electorate in Poland's large and medium-sized cities and towns and its influence on the results of the 2007 parliamentary elections, Bulletin of Geography, Socio-economic Series, Wydawnictwo Naukowe, UMK, Toruń, 13: 103-111.

Matykowski R., Tobolska A. and Konecka B. (1995), Urbanizacja jako czynnik zachowań wyborczych i zachowania wyborcze jako przejaw urbanizacji [Urbanisation as a factor of electoral behaviour and electoral behaviour as a manifestation of urbanisation], in Centra $i$ peryferie duzych miast. Transformacja i przyszlosc. Pojęcia i metody badawcze [Centres and peripheries of large cities. Transformation and funture. Concepts and research methods]. VIII Konwersatorium Wiedzy o Mieście, Uniwersytet Lódzki, Łódź, 83-92.

Matykowski, R. Kulczyńska, K. (2010), Wybory Prezydenta RP w 2010 roku: studium znaczenia elektoratu dużych i średnich miast [Polish presidential election in 2010: A study of the power of votes in big and medium-sized towns], Przeglad Geograficzny, 82, 4: 593-618.

Parysek, J., Adamezak, Z. and Grobelny, R. (1991), Geografia polskich wyborów prezydenckich $1990 \mathrm{r}$. [Geography of the 1990 presidential election in Poland], Przeglad Geograficzny, 63, 3-4: 245-270.

Rocznik Demograficzny GUS (Demographic Yearbook of Poland), (2008), Warszawa.

Rogacki, H. (1988), Czynniki koncentracji przemystu w Polsce [Factors of industry concentration in Poland], Poznań, Seria Geografia, 41, UAM w Poznaniu.

Śleszyński, P. (2007a), Dlaczego Lech Kaczyński wygrat wybory prezydenckie 2005 . Studium z geografii elektoralnej [How Lech Kaczyński won the presidential election of 2005 . A study in electoral geography], Czasopismo Geograficzne, 78, 1-2: 61-82.

Sleszyński, P. (2007b), Druga tura wyborów prezydenckich 2005: czy mozna bylo przewidzieć? [Second round of the 2005 presidential election: was a forecast possible?], Przeglad Geograficzny, 79, 1: 115-132. 
Węclawowicz, G. (1993), Géographie électorale en Pologne, Mappemonde, 2: 6-8.

Węclawowicz, G. (1995), Electoral geography at the national, regional and intra-urban scale, Conference Papers, Warsaw, Institute of Geography and Spatial Organization, PAS, 24: 59-69.

Zarycki, T. (1997), Nowa przestrzeń spotecznopolityczna Polski [New socio-political space of Poland], Warszawa, Studia Regionalne i Lokalne, 23 (56), Europejski Instytut Rozwoju Regionalnego i Lokalnego, Uniwersytet Warszawski.

Zarycki, T. (2001), Rediscovery of environmental influences on the political map. The case of Polish electoral geography, in Antonich M., Kolossov V. and Pagnini M.P. (eds.), On the centenary of Ratzel's Politische Geographie. Europe Between Political Geography and Geopolitics, Memorie della Societa Geografia Italiana, 63, 673-686.

Zuzańska-Żý́ko, E. (2006), Mate miasta w okresie transformacji. Studium $w$ regionie slaskim [Small towns in the period of transformation. A case study in the Silesia region], Katowice, Śląsk Wydawnictwo Naukowe.

Paper first received: October 2011

In final form: December 2011 
http://rcin.org.pl 